Binghamton University

The Open Repository @ Binghamton (The ORB)

\title{
$5-2014$
}

\section{From Biopower to Energopolitics in England's Modern Waste Technology}

Joshua Reno

Binghamton University--SUNY, jreno@binghamton.edu

Catherine Alexander

Durham University, catherine.alexander@durham.ac.uk

Follow this and additional works at: https://orb.binghamton.edu/anthropology_fac

Part of the Social and Cultural Anthropology Commons

\section{Recommended Citation}

Reno, Joshua and Alexander, Catherine, "From Biopower to Energopolitics in England's Modern Waste Technology" (2014). Anthropology Faculty Scholarship. 4.

https://orb.binghamton.edu/anthropology_fac/4

This Article is brought to you for free and open access by the Anthropology at The Open Repository @ Binghamton (The ORB). It has been accepted for inclusion in Anthropology Faculty Scholarship by an authorized administrator of The Open Repository @ Binghamton (The ORB). For more information, please contact ORB@binghamton.edu. 


\section{From Biopower to Energopolitics in England's Modern Waste Technology}

Catherine Alexander, Durham University Joshua O. Reno, Binghamton University

\section{ABSTRACT}

Two energy-generating technologies in Britain which transform waste into a resource are compared. One is the (in)famous Combined Heat and Power incinerator in Sheffield, the other a forgotten biological digester in Devon utilizing anaerobic microbes. Both sites are early exemplars of experimental and biopolitical waste disposal technologies-incineration and Anaerobic Digestion-now regarded as leading alternatives for reducing the United Kingdom's dependence on landfill and fossil fuel; both sites also inspired public resistance at critical moments in their development. The analysis here relates how activists and technicians struggle to demonstrate competing truths about alternative energy. Through comparison, it becomes clear that, beyond the validity of specific truth claims, energopolitics mediate the formation of technological legacies. Examining the traces energy facilities leave behind - whether in the landscape or onlinewe ask what it means that various claims made about some technical operations endure, while others fade into obscurity. [Keywords: Energy, science and technology, waste, Britain, demonstration, memory, legacies] 


\section{Introduction}

Michel Foucault's (2008) notion of biopolitics describes power over life, a characteristically modern form of politics which is intimately linked to statistical techniques that allow for the extrapolation from individual lives to populations. As such, it has been used to characterize everything from race science to reproductive and genomic medicine (see Rabinow and Rose 2006). More recently, biopolitics has been extended to infrastructures that sustain lives (Collier and Lakoff 2008, Gupta, 2012). Here, we examine two examples of such vital infrastructures in the $21^{\text {st }}$ century: technologies to dispose of English waste. However, the timing also exposes other crucial elements, which extend and subvert the idea of biopolitics as initially proposed. Many waste technologies are being reformulated as energy-from-waste plants, thus merging ideas of health derived from hygiene and warmth, and intertwining biopolitics with energy politics. In both of our case studies, public bads-domestic and agricultural wastes-are transformed into fuel and electricity, and this material alchemy brings with it promises of social reforms, sustainable futures, and averted crises.

Given the interdependency of dominant social and political regimes on energy infrastructures (see Mitchell 2011, Boyer this issue), novel energyfrom-waste technologies such as these portend new biopolitical imaginaries. At the same time, we show that local and experimental efforts to supply apparently unproblematic public goods of shared health and heat become entangled in a complex politics of energy privatization which is supported, even subsidized on occasion, by state agencies. Celebrating (or condemning) technical achievements hinges on summoning the right audiences to bear witness to the spectacle (see Barry 2001). In our two case studies, the picture of benign progress is undermined by the rather unimpressed recipients of such munificence. The imbrication of state and corporate interests, public and private goods, bio and energopolitics raises the questions of what exactly is being contested, by whom, and exactly what "the public" is that is being summoned at different points by various parties. As we show, even at the end of these two specific struggles, it is possible to draw quite different conclusions depending on who is telling the story and whether/how it is successfully retold.

Biopolitics has been at the heart of waste technology developments in Britain since the early 20th century. As these technologies were increasingly seen as a means for preserving crowded urban populations from disease, so too did waste management experts begin to term their technologies, and profession alike, "modern." Although both are ancient techniques, burning and dumping were thus promoted as a thoroughly modern means of collecting and eliminating potentially harmful urban waste. It is a striking image: without intervention on an industrial scale, the implication was that human bodies might poison the body politic (see Cockayne 2008). However, it was this very emphasis on care for human and political life that also became a point of contestation between waste technologists and their opponents in the 20th century as civil society groups mobilized through calls for environmental and social justice to campaign against dumping waste near disadvantaged communities (see, for example, Bullard 2000). The struggle, discussed here, was whether benefit to environmental stability and human life had been displaced by short-term profit. The efficacy of both disposal techniques and their management was also challenged. Whether or not waste elimination in this form was indeed a public good therefore emerged as a central theme, accentuated by the broader political climate, where government promoted the private finance and management of erstwhile state-operated services and assets. As documented elsewhere (see Ong 2006:78-79), biopolitics in a neo-liberal context takes on a particular meaning. Here, an attempt to maximize apparently uncontroversial goods - the population's vitality and productivity - becomes a subject of debate: what it is, who should control it, by what means, and in whose name.

But this is only half the story. Transforming waste to energy is, again, an old practice, but one that has recently been championed as creating yet more public goods: fossil fuel alternatives, a solution to climate change, and a steady supply of warmth for citizens' homes. Waste-to-energy technologies present a particularly intimate view of public goods bestowed on private lives: the removal of harm, and its transformation and return into the domestic sphere as heat, via pipes that materialize this link between public and private domains (Marres 2009). The battles that ensued over such apparently beneficent technologies suggest indeed that energy-bioenergy in this case - is profoundly political, and adds to Mitchell's (2011) focus on carbon-based energy as the means to understand modern democracy. The modest infrastructures of alternative waste-to-energy systems have not (yet) supplanted earlier arrangements premised on fossil fuel and landfill, but they still offer new testing grounds for democratic and non-democratic practice. 
The power struggles we outline here suggest that contested views of public and private benefit, and the relationship between them, are central to understanding this form of energopolitics. More than this, a particular kind of knowing, and unknowing, or erasure, also appears as a mechanism of the energopolitics of waste-to-energy technology development in late 20th and 21st century Britain.

In the rest of this article, we give the context for the growth of interest in waste-to-energy technologies in the UK before turning to two instances: an incinerator in the city of Sheffield and an anaerobic digestor in Holsworthy, a rural area in southwest England. In both cases, the exchange of domestic or farm waste for heat was promised, and the plants' development was fiercely contested along similar lines: the allocation of benefits and costs, or goods and bads, in a shifting landscape of commercial, collective, and public interests where appeals to the public good were played out at a range of scales, each serving to displace others. The content of the public good from these schemes also morphed between an emphasis on environmental and human benefit, variously defined at local and global levels. ${ }^{1}$

In these senses, the struggles over each plant were construed along broadly analogous lines. However, this does not explain the curious difference in material and virtual legacies within and between these schemes. The Sheffield incinerator remains iconic for both protestors, who believe they succeeded in shutting down an earlier incarnation, and proponents of the scheme, who hail it as a successful exemplar of district heating. Both accounts are still visible on the Internet. In contrast, the fracas over the Holsworthy biodigestor has all but vanished. While Holsworthy is largely neglected as a forebear to later bio-digestors, both thermal treatment supporters and detractors frequently reference Sheffield as, respectively, a model for both the spread of a new generation of incinerators, and how incineration can be resisted. Both activists and engineers benefit from engaging with sites that allow their truth claims to endure. But what accounts for this differential success in not only making claims, but making claims which reshape public imaginations of energy, life, and waste?

We are thus interested in how energy infrastructures and technologies become "publicized," in excess of the outcomes they are designed for This means tracing "public" in its other guise, not merely as the counterpart to a range of differently constituted private spheres (Warner 2002:6), but as constituting a collective with shared interest. The contested mediation of such sharedness via the fractured public sphere has been well documented (see Fraser 1992, Warner 2002), but the question of what makes for lasting public engagement-the substance of political participation-has arguably remained more elusive. In her book, Material Participation, Noortje Marres (2012) borrows from the pragmatist tradition of Dewey and Lippmann to consider the issue-orientatedness of public engagement. In her account, material publics represent "the community of the affected" (2012:50), people with shared interest in a common issue of concern. Such concerns are elevated in areas of scientific and technological controversy, where social antagonism is mediated by the exclusivity of expertise (Wynne 1992).

In techno-scientific controversies, publics appear in multiple forms. We use the concepts of memory and legacy as a key to comparing technocratic experiments, and their ability to foster not only health and energy but to sustain engaged publics of different kinds, including experts, bureaucrats and financiers, local citizens, anarchists, environmentalists, and bloggers. The example of Internet sites is particularly useful in exploring the realm of memory because it increasingly serves as a record of events, and for that reason, websites could also be described as virtual "carriers of democratic process" (Marres 2004). To the extent that material publics are brought into being through "issue-networking," the absence or cessation of virtual forms of political engagement is worth noting.

Scholars in science and technology studies (e.g., MacKenzie and Wajcman 1999) have noted that forgetting past controversies, innovations whose operational success was uncertain, or alternative technological paths is part of the implicit material politics of technological change. In our case studies, and as is evident in transitions within the waste industry throughout Britain and Europe, past controversies and concerned publics are also forgotten to make way for imagined national and global futures associated with energy and climate in crisis. As Andrew Barry (2001) argues, whether one is an engineer, policy-maker, or an activist, acts of truth telling must be anchored in particular sites and moments of demonstration. Barry emphasizes that successful demonstrations rely on the figuration of proper witnesses to truth, but adds that the particular enactment of demonstrations is also a material affair. We argue that as a means of truth-telling about pasts and futures, the Sheffield and Holsworthy sites prove variously frail or obdurate, tangible or virtual, dull or spectacular. It is for these reasons that the former has endured in public memory and imagination, while the other has been largely forgotten. 


\section{Regulative Context}

Together, the Sheffield and Holsworthy sites represent early exemplars of what have become the main alternatives for dependence on fossil fuel and landfills in Europe and elsewhere. The European Commission's Landfill Directive (1999), Waste Incineration Directive (2000), and Renewables Directive (2009) demanded that specific member states curtail landfill use, modernize incineration methods, and increase renewable energy production, all partly for the sake of reducing carbon emissions and averting global climate change. Over the last decade, two different UK governments have responded to these directives by encouraging innovation and investment in the production of energy from waste, subsidizing the privatization of waste management and backing demonstrator projects. In word and action, "waste" is being redefined as "resource," but uncertainties remain and excess or leftover remnants haunt the official images of closed cycles of material reuse.

\section{The Sheffield Energy Scheme}

Sheffield, in the heart of England's midlands, is an industrial city, long famous for fine cutlery and mass produced steel. Largely as a result of the concentration of steel workers, 19th century Sheffield became a center for trade union organization and for attempts to resist the expansion of capitalist industry. Following the 1973 oil crisis, unemployment rose sharply, but, as the rest of the country came under the sway of the neoliberal policies, left-wing politics in Sheffield endured. In the 1980s, a conservative member of parliament coined the nickname "The People's Republic of South Yorkshire" for Sheffield and its hinterlands, a name enthusiastically adopted by local residents and authorities (Seyd 1990). Having peaked in the 1950s, there was a steady population outflow from the 1970 s as unemployment levels grew (Winkler 2007).

This is the staunchly socialist background to Sheffield's postwar slum clearance and their replacement in the 1960s with huge complexes of public apartments on the biopolitical grounds of improving the health, sanitation, and well-being of the people. ${ }^{2}$ The new complexes were revolutionary in design, incorporating the latest social and technical innovations and explicitly following the spirit, if not the construction excellence, of Corbusier's L'Unité d'Habitation in Marseille. Built on reclaimed waste ground, each flat was fitted with a Garchey refuse disposal unit: a water-borne system "whereby the refuse is untouched by hand from the time it is placed in a special kitchen sink unit until it is removed as ash from the incinerator at the terminal point of the system" (Sheffield City Council 2010:19). Thus, Sheffield's waste not only provided the ground upon which construction of public housing began, but it also provided energy. A network of underground, pressurized hot water pipelines joined each apartment to the city's incinerator, returning waste as underfloor heating. One of the largest and most celebrated complexes was Park Hill, which opened to great fanfare in $1961^{3}$ (Watts 2004, Mollona 2009:65). The Park Hill complex embodied the seamless connection of private and public life, transforming not only waste ground into the latest living conditions but, arguably, transforming residents themselves via the exchange of private waste for publically generated and redistributed warmth - and thus health and happiness. If coal-producing regions like the Midlands helped provision the energic infrastructure of carbon democracies (Mitchell 2011), then this was ostensibly socialist planning premised on collective benefit from the reuse of refuse, a common image in visions of socialist utopia. 4

There were early problems, however. It appears that both the heating system and housing complexes suffered from lack of maintenance, in common with many other British public housing estates in this period (Alexander 2008). As Abram (2006) notes for Sheffield's Norfolk Park Estate, one of the problems with adequate heating supply, as opposed to simply returning heat, was that the flats were single glazed and poorly insulated; much heat generated for the public good (admittedly at a fixed charge for the recipients) was therefore literally lost to the winds. Memories now of life in Park Hill are similarly critical, often centering on those very aspects that had once made them so celebrated. As one blogger writes:

Then there was the incinerator: rubbish was burnt in a boiler house, and the heat from your junk piped through the radiators (for an astronomical fixed fee of $£ 9$ per week, summer and winter). Sometimes there'd be problems with the incinerator, or the wind would blow in the wrong direction: I once found my nice new carpet and my son's toys covered in a thin layer of little black specks. In the old days they called it soot and demanded clean air! (Jones 2007)

In other words, it was the very material infrastructure that enabled the exchange of privately produced waste for public health and warmth that was 
faulty and was experienced simply as a continuation of the bad old days. On an Internet chat forum dedicated to Sheffield history, one contributor recalls inadequate garbage collections:

I don't think they had bins on the upper decks. They didn't when my sister lived there. It would take them a month of Sundays to traips [sic] up and down the service lifts to empty them that wasn't already thrown overboard. Wasn't all this rubbish transferred to some "oven, inferno" that heated the whole block. That's what we were all told at the beginning of these "beautiful" new blocks of flats, that they were self sufficient [sic]. (Sheffield Archives, Ukele Lady 2011)

The last comment is worth noting. It has been suggested that existing neoliberalism is fundamentally contradictory, removing the structures and supports to enable more deprived members of society to engage in the market on an equal footing. Arguably, it is welfare states, as opposed to those committed to minimizing public intervention, which provide the requisite support to enable relative citizen autonomy, or as in the words of the last quotation, "self-sufficiency"; a particular spin on the notion of technologies of power. However, nominal self-sufficiency can be experienced quite differently, as the quotation suggests.

\section{The Holsworthy Energy Scheme}

Holsworthy is a small market town in the southwest of Britain. The surrounding area, irrigated by the Tamar River, has been largely agricultural for centuries. Like most of the rural UK, Holsworthy suffered from falling incomes, and rising costs of farming in the late 20th century, which were exacerbated by the outbreak of agricultural epidemics such as Footand-Mouth and Bovine Spongiform Encephalopathy (BSE) (also known as Mad Cow Disease [MCD]). Unlike Sheffield, where the disappearance of heavy industry led to net population loss, economic decline in the southwest has coincided with population growth. Since the 1980s, the region has grown faster than any other in England, by over 13 percent, mostly through migration from London. As more English people choose to settle down in the countryside, rural inhabitants have to contend with alternative conceptions of "rurality" (Murdoch and Pratt 1993), including different ways of valuing the landscape and accompanying shifts from agriculture and industry to tourism and a more service-oriented economy (Bouquet 1982).

The increasing population in the southwest has coincided with concern about growing energy needs and the risks of carbon-intensive energy solutions. In order to reduce reliance on fossil fuels, the southwest has been pursuing several alternatives. Within the counties on either side of Devon (Somerset and Cornwall), experimental nuclear, wind, wave, and waste energy facilities are undergoing development, typically with the help of private investors and designs from elsewhere in Northwestern Europe. Within rural Devon and neighboring Dorset, however, alternative energy has taken a very specific form.

In the area surrounding Holsworthy, there has traditionally been a high density of cow, pig, and chicken feces, or "slurry," per acre, which began to cause disputes in the 1980s over what constituted the countryside's proper enjoyment and use. It was for these reasons that the North Tamar Business Network (NTBN) sought an alternative means for disposing of their animal slurries in the early 1990 s. $^{5}$ At this time, they approached a technical advisor and proponent of rural development, Claire Lukehurst, who did an assessment of the area and the technical options available.

Since the 1970s, farmers throughout the UK have experimented with anaerobic digestion $(A D)$ - though this fact is rarely acknowledged in the official discourse of the contemporary waste industry or central government, which tends to emphasize its novelty as a solution to waste disposal and energy generation. In the country's remaining agricultural pockets, new techniques for harnessing waste were adopted in order to dispose of slurry more sustainably and reduce dependency on nitrogen fertilizer and fossil fuels. AD is a natural process that involves the microbial decomposition of organic materials without oxygen. The products of this process are digestate, an odorless, dirt-like substrate high in nutrients, and biogas, a methane-rich gaseous mixture exhaled by the microbes. Because digestate does not smell, it does not release noxious odors when spread over the fields, as unprocessed slurry does. Furthermore, the biogas that comes from anaerobic methanogenesis can be used for heat or converted into electricity.

To harness this process, all that is needed is some method of containing the material breakdown particular to $A D$, whether it is encased underground, as is done cheaply throughout the "global south," or above ground in large tanks. AD not only allows the inputs or "feedstock" used 
to be controlled, but also potentially the $\mathrm{pH}$ and temperature so that more biogas and better digestate can be extracted per liter of biomaterial.

The existing model of AD plants in the UK was too small-scale to deal with the NTBN's requirements, and would require investment from each individual farming household (Reno 2011a). By pooling their resources Lukehurst and her clients reasoned, they could create a bigger digestor that catered to all their farms and provided heat for all of them as well as the village. $A D$, farmers hoped, would not only improve their relationships with new arrivals from the city, but also keep their farms going by providing an additional source of revenue. Given that the town of Holsworthy was in the middle of the region's greatest density of farms, the AD plant could sell its electricity, at a subsidized price, to power the cottage hospital, the old people's home, the schools, and the industrial estate all within half a mile. In this way, the plant promised to provide rural development beneficial to all residents while simultaneously modernizing and rewarding farms.

The NTBN decided that a Community Energy Programme Grant ( $£ 600,000)$ should be pooled with the EU grant ( $£ 3.85$ million) and the NonFossil Fuel Obligation (NFFO) subsidy (a 15-year price of £58 per megawatt of energy produced) in order to develop the plant and the local power scheme. On this basis, Lukehurst's proposal was initially approved by the steering group, the local district councils, the Environment Agency, and government. In order to help the relevant "decision-making farmers" make an informed choice, they traveled to Southern Denmark to visit farms and meet the environmental health, veterinary services, and corporate actors who built similar plants there.

According to Derek, one of the local farmers who initially bought into the scheme, the businesspeople from Germany were inspirational: "Their enthusiasm came all across to the farmers who thought 'wow!,' they all saw the pound signs going up... They were infected with this enthusiasm and the problem is they hadn't really thought it all through."

After initial planning permission was given, and the site built, some local opposition died down. In 2001, construction began on the largest and first centrally-located AD plant in the history of the UK. By 2003, the two 4,000 cubic meter digestors were operational under the auspices of Holsworthy Biogas, at a cost of $£ 7.8$ million. Though the local energy scheme had not been completed, the plant could now take in residues of the food production system. Local farmers could store most of their slurries in collection pits and trucks would come to exchange it for biofertilizer from the plant.

\section{The Sheffield Incinerator and Its Qualified Success}

Five years after completion of the Holsworthy plant, anaerobic digestors would be championed by various UK government agencies as a leading waste disposal method of the future, at the same time that more established waste disposal methods-landfill and incineration-were becoming targets for European governance. 6 Just as the Holsworthy digestor was becoming operational, changes in incinerator regulation were being introduced across the continent. Anticipating the $2000 \mathrm{EU}$ Incineration Directive, Sheffield's public-private partnership for managing municipal waste, Sheffield Heat and Power Ltd., ${ }^{7}$ began to upgrade their elderly incinerator at considerable cost ( $£ 25$ million), simultaneously extending the reach of the heating network (currently over 44 kilometers) to heat public buildings and more residential districts (Owen 1992). Abram (2006) notes that this very improvement also presented challenges to the next cycle of destruction and renewal of the housing complexes since many of the original construction plans disappeared and with them, it is said, common knowledge of many of the underground pipes and unstable geology of the area.

In May 2001, a French waste management company, Onyx, later renamed Veolia Environmental Services, was awarded a 30-year contract to manage Sheffield's integrated waste services starting in August 2001. While Veolia Environmental Services presents the upgrading and enlargement of Sheffield's district heating system as a seamless story of continuous improvement for public benefit, there have been several controversial and well-publicized interventions by anti-incineration activists.

The same month that the contract was awarded to Veolia, Greenpeace activists climbed the 75 meter high incinerator chimney and painted "toxic waste" in huge white letters down it. Five activists camped on the chimney for three days, capping it with a tarpaulin decorated with a skull and crossbones, while another six protestors chained themselves to machinery in the main areas for receiving waste. Citing Environmental Agency statistics, Greenpeace claimed the protest was lawful, suggesting that "[the] Sheffield incinerator is the worst in Britain and has broken legal pollution limits 178 times in the past 3 years" and that their action was 
the "equivalent of a citizen's arrest of a repeat offender" (Greenpeace) Sheffield Council applied for and obtained an injunction to end the protest. The protestors were tried, released, and claimed the action to be a victory in preventing toxic pollution for three days. The entire protest was covered on national television.

On June 25, Onyx announced that it would close the incinerator, since the costs of increasing standards to meet the Waste Incineration Directive would exceed that of constructing a new plant. Anti-incinerator activists hailed the closure of the old incinerator as a triumph. The problem with framing public concern in terms of the age and quality of a technology, however, is that it implies that the way forward is newer and better technology. Not long after the closure, it was announced that a new, larger capacity, more technologically-advanced plant would be opened in Sheffield. Planned for 2006, the new incinerator was now christened an "Energy Reclamation Facility" (ERF) and equally celebrated as state-ofthe-art technology by Onyx and Sheffield City Council that would provide both electricity and heat to the district heating system and to the citizens of Sheffield in their homes and public buildings.

The protestors continued their campaign. On September 29, 2003, a demonstration was held in Sheffield's city center with, among the speeches, a song based on Pink Floyd's anthem "Another Brick in the Wall":

We don't need incineration

We don't need this dirty air

Birth defects and cancer clusters,

Kids with asthma everywhere.

Hey, Onyx, leave those kids alone!

We don't want another...brick in the wall.

We all want our waste recycled

It's a crime to burn it all

Precious oil lost forever

Global warming haunts us all. ${ }^{8}$

The protestors were campaigning for less emphasis on incineration (presented by the City Council and Veolia as the only pragmatic option for effective municipal waste management), and more prominence given to recycling and composting. The campaign made extensive use of the Internet. ${ }^{9}$ Central to the campaign's validity were also letters to the Council from local medical doctors suggesting that the incinerator was harmful to local public health.

In 2008, Veolia submitted an application with the Council to extend the catchment area for the ERF, drawing in the waste of three more local towns: Doncaster, Barnsley, and Chesterfield. The justification was that wastes collected for the ERF had declined since the contract was first signed, meaning that this income stream could not be realized; forecasts indicated a continued downward trend. The perceived expansion of Veolia's original remit continues to be contested locally as activists describe this move as transforming Sheffield into Yorkshire's rubbish bin. The struggle continues.

\section{The Holsworthy Digestor and Its Productive Failure}

Shortly after the new ERF was built in Sheffield, the new anaerobic digestor in Holsworthy was declared a failure. Despite the optimism and enthusiasm associated with the plant's conception and development, after a few months it became apparent that its business model was not viable. According to informants, Strathclyde University first reported on the problem, concluding that the primary feedstock was not viable for gas production and that government subsidies or more gate fees would have to subsidize it. 10

Eventually, the public limited company that owned and operated the plant declared bankruptcy. This spurred a management buyout and a reorganization of funds that involved more investment on the part of local farmers. Summerleaze Andigestion, the private firm that eventually purchased the plant, later claimed that abandoning this agricultural model and taking in more food waste and other food residues could solve its commercial woes. As with the Sheffield incinerator, "the public" supplying the facility had to change-when closed loops prove economically unviable, they require supplementation through non-local and delocalizing commercial contracts. The initial planning application for the Holsworthy digestor included a fraction from other food residues, particularly animal by-products like abattoir waste. Initially, the idea was that this would provide enough additional revenue from gate fees to subsidize free disposal of local farm wastes. In the early years, the plant supported 120,000 tons 
of cattle, pig, and poultry manure annually and 30,000 tons of additional residues from the food production system. With so much material, roughly 80 percent, entering the plant at no charge, it was difficult to run at a profit. The difference could be made up in the sale of biogas for energy, at a subsidized price, as planned, but as the Strathclyde report demonstrated, cattle slurries limit gas production when compared with other food residues. ${ }^{11}$ The alternative that the new firm proposed and pursued was to take waste from outside the community in greater amounts, just like Veolia's proposal for Sheffield's incinerator. A year after Summerleaze made the acquisition, they applied for planning permission to change their feedstock limitations. ${ }^{12}$

Part of the flaw with the original financial model, in other words, was that it eschewed profitability and energy productivity in favor of a technology that would primarily take community wastes and return them to the community in the form of heat and fertilizer. From the beginning, however, the Holsworthy plant faced difficulties acquiring the funds to create its heating scheme. The energy company established to manage the project successfully sold electricity to the national grid, but could not finance the local heating scheme. The initial cost of the project was just under $£ 2$ million and the Community Energy Programme Grant provided barely 25 percent. With an estimated net cash flow of $£ 375,000$ after 20 years, moreover, the plant could not find private investment to make up the difference. Energy was being sold on the national grid at a premium price, but because of insufficient funds from the grants they received, the pipelines laid in the ground were never hooked up to provide heat to local community buildings as promised. Whereas the actual network of pipes in Sheffield were lost to memory in Holsworthy they only ever existed virtually, in the original designs of Lukehurst and the NTBN. With fuel poverty a growing national concern, local council housing would still benefit from completing the project, but Summerleaze struggled to find enough public or private funds to realize its original ambition.

When local opposition began to grow towards the Holsworthy digestor, it was not in terms of this unfulfilled potential, but perceived threats to animal health and the spread of odor, as well as inadequate roads. ${ }^{13}$ In 2007, several locals met their Member of Parliament in order to prevent Summerleaze from gaining permission to increase their intake of wastes from outside the community. According to Derek:
They'd already been bringing up more and more food waste and blood and slaughterhouse waste... We were told that the plant was supposed to be about, you know, cow manure basically. So that basically started us off protesting...It came about fairly quick, I suppose, we called ourselves just the Holsworthy Biogas Protest Group [HBPG].

The HBPG started up a website forum to express local concerns about the plant and spread information to other communities about the risks of poorly run AD operations.

According to members of the HBPG, Summerleaze "started to sneak food waste in" before the planning application was approved, after they failed to collect enough poultry and pig manure. ${ }^{14}$ This included contraband seized by HM Customs and Excise-such as tobacco, perfume, and alcohol; glycerine from a Devon biofuel plant; and waste from fish markets in Plymouth and Newquay, other southern towns. With such a variety of biological wastes from all over the Southwest, some local residents became alarmed at what they saw as possible danger. For farmers and rural dwelling people, these risks evoked memories of the costs and fears associated with the Foot-and-Mouth epidemic of 2001, an outbreak that sorely affected relatively poor areas of the Southwest. According to another member of the HBPG:

Now BSE, CJD [Creutzfeldt-Jakob Disease], Foot-and-Mouth was all imported from other countries to the point of distribution. Right? Now, when they decided to use cattle offal, cattle blood, I thought of them slaughter houses, I'm thinking they go to the slaughter houses because there's something wrong with 'um. So what disease are they gonna bring to Holsworthy and spread around our local farms?

The fear of inadequate pasteurization and the possibilities of disease transmission are especially acute because of the sense that the wastes going to the plant are not only from familiar farms in the area, but potentially from all over England and abroad as well. These concerns are especially salient to an aggrieved farming public that has learned to mistrust technocratic assurances. The Holsworthy plant is designed to contend with such uncertainties, primarily by assuring that temperature levels in the tanks remain high enough to destroy potential contaminants. But, as 
Hinchliffe (2001) argues, such technical fixes only appear to resolve what are much more open-ended and indeterminate risks, which, in the case of animal epidemics in particular, tend to involve much broader geo-political relations (see also Law and Mol 2008).

With concerns about traffic, safety, odor, and disease transmission, the HBPG continued to update their (now defunct) website, call public meetings, circulate petitions, distribute fliers, and link their activities to other groups experiencing similar problems elsewhere in Britain. But in 2009, the HBPG abruptly disbanded. According to Derek, speaking on behalf of the group, "We feel we've come a long way and think the plant is helping the public. There is a much better set up now than in the past and they should be praised at Summerleaze." The original protest group targeted the operations of the plant in particular and therefore ceased to exist once this issue appeared to be resolved. ${ }^{15}$ Arguably, unlike an environmental institution like Greenpeace, the HBPG lacked the organizational memory and material resources for its protest to remain visible and endure after it had concluded.

As with the Sheffield incinerator, however, this resolution is incomplete. The members of the HBPG now campaign for the provision of proper roads to support vehicles on their way to and from the site. It is this infrastructure that concerns them, and not the original energy scheme designed to benefit the wider community. That the roads are now the primary matter of concern for "the community of the affected" (Marres 2012) is at least partly because the cause for their involvement came out of private commercial and domestic interests-being protected from harm and nuisances and maintaining property values - rather than the more ambitious agenda of reforming the distribution of energy. The latter would have required a much more radical change in local energopolitics, beginning with putting pipes in the ground. In 2013, the energy scheme remains underfunded and incomplete.

Despite the resolution of differences between Summerleaze and the HBPG, it could be argued that neither group succeeded in wholly demonstrating their truth claims to wider publics on a national scale, as both Sheffield's engineers and protestors have arguably done. By 2007, while Holsworthy continued struggling to finance its local heating scheme, smaller-scale, less collectively-based forms of $A D$ were being promoted by government agencies and new waste industry start-ups as a primary disposal method-alongside incineration - for meeting renewable energy needs and reducing carbon emissions and reliance on landfills. And yet, most of the ensuing national and international discussions of this method failed to acknowledge the difficulties that the implementation of AD faced in Holsworthy, or recognize its potential as a model to be duplicated (or avoided) in the future, even as similar Northern European technology from Denmark and Germany was increasingly adopted throughout the UK (with similar consequences, see Reno 2011b). The removal of the HBPG website, furthermore, disallows environmental justice activists from learning from their example, as they might from Greenpeace's archived documentation of the Sheffield actions.

\section{Conclusion: Spectacular Contests}

There are striking similarities and differences in these accounts of Sheffield's incinerator and Holsworthy's digestor. Most obviously, they involve the alchemical transformation of waste into forms of value. The wastes we consider-farm and domestic-are perceived and engaged with differently by different publics: some farmers would gladly spread untreated manure on their fields and some people would happily hurl offal from their open windows onto the streets. It is arguably the polyvalency of waste that makes it an attractive area for socio-material experimentation: a bad that can be made to do good and therefore allow for alternative biopolitical futures to be imagined, carved out from the prevailing energobio-political regime of fossil fuels and landfilling. Both case studies also foreground a number of linked concerns that characterize contemporary energo-politics in England: the shifting (moral) landscape of public and private regulation, ownership, and finance; contested ideas of what constitutes public or communal goods and bads; and the proliferation of different publics who are enrolled, mobilized, appealed to, and used as a source of legitimation by various parties at different times. The way that these publics take form, and do or do not last, hinges in part on the materiality of participation (Noortje 2012) and involves distinct scales of environmental and social benefit.

European regulation over waste technologies was responded to in England by government financial support for local administrations to privatize waste management on the one hand and to run "demonstrator" projects of "new" alternative technologies on the other (Reno 2011b). In Sheffield and Holsworthy, local and national perception of the respective 
technology took a critical turn as local municipal or community ownership of the sites changed to private hands and the ideological narrative of public gift was jeopardized. This critical turning point allows us to trace the social fault lines that emerged as "black boxes" were opened and matters of fact became matters of concern for affected publics (Latour 2005). Shifts in ownership were accompanied by technical innovations to bring better profits and reduce risks, and such changes developed in concert with the concerned publics they engender (Marres 2009:119). What was evident in both cases was that the old line that private vice, or profit maximization, leads to public benefit did not hold among certain groups of the affected, or at least was fiercely contested. As "gift-giving" technologies changed how they operated, the recipients of transformed wastes also shifted in scale. Thus, both private firms sought to extend their catchment areas to realize incomes streams based on throughput. This problematized the argument that these were local concerns and, far from being an easy translation to public benefit, was contested in both cases as damaging to local well-being.

What exactly counted as a public good was clearly not straightforward either. Ideas of the public good have variously appeared here as: enjoyment of the countryside as landscape, poverty reduction, efficient domestic and farm waste disposal, free fertilizer, sanitation, warmth, and a reduction in carbon use and methane production. Not only do these goods appear to be rivalrous, but the validity of some claims was questioned. Thus, the warmth supposedly generated from the original Sheffield incinerator was, according to bloggers' memories, faulty: the apartments were poorly glazed and insulated, the pipes incorrectly calibrated, and the incinerator often failed or emitted pollution-thus harming, not improving health - and provided costly, not cheap, electricity and heat. The anti-incineration activists also claimed that dioxins produced by thermal combustion were injurious to health. Similarly, the additional feedstock that Summerleaze sought to acquire (and according to some, was already acquiring illegally) was meant to sustain the viability of the biogas enterprise in Holsworthy, while members of the HBPG identified it as a possible source of disease.

Added to this mix was the mutating nature of the publics which were supposedly enjoying the benefits. Protestors, municipalities, engineers, and companies all engaged different publics with their truth-telling performances. And there is no reason that forums assembled through official planning approval meetings are any more salient than the readership of a blog on Sheffield history, nor can we assume that Summerleaze and Veolia or Greenpeace and the HBPG appeal to the same publics, when some fail to cohere and others appear to last. The narratives of some publics remain durable even after the shared problems that initially bring them together and material sites that organize them fade away. The enduring influence of Sheffield's waste technicians and activists is clearly rooted in actual pipes connected, if now forgotten, and actual stacks climbed and graffitied, if now only visible on the Internet. With this shift in the particular materialization of truth-telling sites - whether in the ground or online-one can identify a fragmentation of different publics, a loss of meaningful overlap, and shifts in scale. Advocates of thermal combustion presented Sheffield's incinerator as a success on the grounds of pragmatism - a bottom line as it were that brooks no dissent-and by appeal to a global humanity that profits through carbon reduction. This larger public effectively trumps local claims, even if those are for the city of Sheffield.

This shift of scale in publics is a tipping point in both instances. The bio-political projects of the state, classically enacted through large-scale infrastructural projects for the well-being of the population here shift to private operators (Veolia and Summerleaze), operators that would not exist at all were the business of waste not privatized to begin with. They are thus able to profit by taking private/domestic waste and charging both for the removal of threats to the health of the local and global body politic and for the provision of power to private and public buildings alike. Arguably, the energo-politics at the heart of new energy technologies and their infrastructures are made explicit through legitimating appeals to a vast public good of carbon reduction and the spectacular creation of grand material and social technologies for waste collection and power redistribution. But the politics at the heart of these energy enterprises simultaneously disappear precisely because the scale has shifted from the local, even the local monumental, to a notion of a global good.

The last point that connects these concerns is the longevity (or otherwise) of alternative claims and voices. Since many of the disputes were themselves about different understandings of the legacies of planned energy-from-waste developments, the durability of the incinerator's protest on the Internet, as opposed to the ephemerality of the digestor's protest group's website and arguments is worth puzzling through. We suggest that what appears here is a particular form of spectacular energy politics, 
where some claims are recognized and live on in public memory, while others are not only trivialized into obscurity, but must be erased to allow the trope of continual innovation to succeed. Unlike Debord's (1992) view of spectacular politics, however, not all subversive claims to truth are simply removed or reincorporated: the highly visible protest of the antiincinerators lives on alongside the new incinerator in a virtual domain. Each instance reveals different engagements with public spectacle as a form of technological legitimation. This, therefore, offers a different take on the familiar question of how and why some technologies are taken up and others are not (Bijker 1995, Geels and Schot 2007, Geels 2006).

Tracing the controversies that routinely unfold over governmental and corporate promotion of purportedly "new" energy technologies, the types of resistance, negotiation, and collusion they engender, and their legacies is instructive. This "newness" responds to a framing of development and progress, but often depends on selectively forgetting what came before and thus obscuring what else could come to be. Thus, the struggle to introduce new energy-from-waste technologies is not only about the particularities of technical innovation, but involves the mediation of public memory and technological imagination, both on and offline (Clark 2007; Cooper 2008, 2010; Alexander and Reno 2012).

At the very least, this suggests that there is something about the spectacular and the grand in energo-projects that gives a curious longevity and stickiness to the politics with which they are imbricated. At a simple level, claims of success and defeat (whether by technocratic or anarcho-environmentalists) are simply fought out in wider public spheres and more can be made of bigger, ambitious technical spectacles. If this is the case, then there is a sharp lesson to be learned from the fact that small-scale, often rural energy experiments are easily, or indeed functionally, forgotten by engineers, policy makers, or activists in campaigns to increase the use of AD.

Key to these two accounts of contested waste technologies and their equally contested success or failure is the notion of demonstration: the spectacular allows for a sense of public confirmation that these technologies work or do not. The unspectacular disappears from view, and, with such evaporations, the memory of lessons learned equally vanishes from sight-and thus from the narrative of technological progress. Without incorporating the memories and legacies of small-scale experiments into the hesitant advance of different technologies, we fail to understand what is happening on and in the ground. The question that, therefore, remains is how to concoct smaller-scale energy experiments that affect and enrapture the right publics.

Acknowledgments:

The authors acknowledge the support of the Economic and Social Sciences Research Council (grant Res-060-23-0007). We also would like to thank the two anonymous and generous peer reviewers for their hugely helpful suggestions and Dominic Boyer for his exemplary work assembling this special collection.

Endnotes:

1The conceptualized divide between public and private spheres varies depending on socio-political and historical context (Rössler 2004), and is arguably linked to forms of biopower (see, for example, Santoro 2009). Our use of the public/private binary to discuss the apportioning of goods is intended to highlight the importance of this ideological division of spheres for liberal and neoliberal rationalities of governance, while showing the mutability of what these terms actually mean in practice.

${ }^{2}$ This was the culmination of the 1935 representations made by Dr. Rennie the City Public Health Officer on the damaging effect of crowded slum dwelling on health (Sheffield Archives: CA-MIN/74, p. 221 as quoted in Sheffield City Council 2010)

${ }^{3}$ The municipal administration printed a brochure on the city's new housing schemes in, among other languages, French and Russian (Abram 2006).

4Fellow exiles Victor Hugo and Pierre Leroux were vocal proponents of the "circulus," a vision of a socialist utopia where the sewers of Paris would be tapped as a vital resource (Reid 1993:54). Leroux developed this notion as a solution to the population crisis proposed by Malthus; if the circulus were adopted in Paris, he wrote, "Each would religiously gather his dung to it to the State, that is to say the tax-collector, in place of a tax or personal levy. Agricultural production would double immediately and poverty would disappear from the face of the earth" (as quoted in Reid 1993:55).

${ }^{5}$ Small firms like the NTBN represent a growing British tendency, with the widespread mechanization of farm labor in the early 20th century, for interfarm cooperation to consist primarily of contract-based specialized enterprises (Jones 1973:46).

${ }^{6}$ The Department for Environment, Food, and Rural Affairs (DEFRA) sponsored special demonstrations to test the viability of $A D$ (Reno 2011b) and the Office of Gas and Electricity Markets incentivized the sale of electricity from Anaerobic Digestors to fulfill renewable energy quotas (Reno 2011a). Similarly, quasiNGOs under the auspices of DEFRA, such as the Waste and Resources Action Plan, worked to establish quality standards for the sale of digestate as fertilizer.

${ }^{7}$ Sheffield Heat and Power Ltd. (including British Gas and Sheffield City Council) was set up in 1984, and became operational in 1987. In the late 1980s, a heating pipe network began to be extended to include Norfolk Park complex in order to heat public apartments there. The cost was passed on to residents. The pipelines were abandoned and were not used in subsequent retrofits of the public housing complexes that are now sold as private apartments.

${ }^{8}$ Such protest songs and chants are themselves "carriers" (Marres 2004) that facilitate democratic action among certain publics, that is, they are a way of aligning different people according to shared backgrounds; those who know Pink Floyd would identify this song as one of rebellion, here reframed to target the eco-themes of environmental justice, global warming, and recycling.

${ }^{9}$ The campaign website is still accessible online at http://www.greenpeace.org.uk/search/node/ Sheffield\%20incinerator.

${ }^{10}$ Some experts on $\mathrm{AD}$ claim that the large-scale nature of the project was to blame, constructed on the model of larger digestors of continental Europe, where smaller-scale AD plants tailored to individual farms are more sustainable in the long run. "This was supposed to be the future!" AD inventor James Murcott would later tell us, and yet it was not helping to create sustainable, profitable agriculture as promised. 
${ }^{11}$ Moreover, with the introduction of the Renewables Obligation (or RO) in 2002, the guaranteed NFFO price was far less attractive. ROC prices in the mid-2000s were peaking at £90 per megawatt, nearly twice the value of the contracted price that the Holsworthy plant had received. The RO was being touted as the future of policy at the time (see Reno 2011a), as it commoditized renewability as a separate revenue stream from the sale of the electricity itself.

${ }_{12}$ Using more food waste as feedstock for the plant, they claimed, would increase gate fees and the production of saleable gas. Food waste has twice the gas potential of cattle slurry and people will pay the
plant to take it. ${ }^{13}$ Shortly after taking control of the plant, Summerleaze attracted public scorn for its involvement in an environmental leak in nearby Boyton in 2006. Summerleaze reported to the Environment Agency that slurr had escaped from one of its 300,000 liter holding tanks and entered the River Tamar, where it reportedly killed multiple fish (Lets Recycle 2006).

14Poultry and pig manure were important to the scheme because, unlike the dairy farmers who had helped finance the project, they were counted on to pay a fee to use the plant. According to some, there were difficulties getting the digestor to process chicken droppings and the biggest pig farmer in the area refused to pay for the service.

15This resembles how those affected by demonstrator waste sites elsewhere in the country saw differences resolved through technical innovation and adjustment on the part of offending plants (Reno 2011b).

\section{References:}

Abram, Simone. 2006. "Materializing Identities Bricks Coming Out of the Ground: Reconstructing Norfolk Park." Materializing Sheffield: Place Culture Identity. Accessed from http://www.hrionline.ac.uk

Alexander, Catherine and Chris Smaje. 2008. "Evaluating Third Sector Re-use Organisations in the UK: Case Studies and Analysis of Furniture Re-use Schemes." Resources, Conservation and Recycling $53(5): 719-730$.

Alexander, Catherine and Joshua Reno. 2012. "Introduction." In Catherine Alexander and Joshua Reno, eds. Economies of Recycling: The Global Transformation of Materials, Values and Social Relations, d-34. Eondon: of Recycling

Barry, Andrew. 2001. Political Machines: Governing a Technological Society. London: Athlone Press.

Bijker, Wiebe E. 1995. Of Bicycles, Bakelites and Bulbs: Towards a Theory of Sociotechnical Change. Cambridge: The MIT Press.

Bouquet, Mary. 1982. "Production and Reproduction of Family Farms in South-West England." Sociologia Ruralis 22(3-4):227-244

Boyer, Dominic. 2011. "Energo-politics and the Anthropology of Energy." Anthropology News 52(5):5-7.

Bullard, Robert D. 2000. Dumping in Dixie: Race, Class, and Environmental Quality. Boulder, CO: Westview Press.

Clark, John. 2007. “'The Incineration of Refuse is Beautiful': Torquay and the Introduction of Municipal Refuse Destructors." Urban History 34(2):255-277.

Cockayne, Emily. 2008. Hubbub: Filth, Noise \& Stench in England 1600-1770. New Haven: Yale University Press.

Cole, lan and Robert Furbey. 1994. The Eclipse of Council Housing. London: Routledge

Collier, Stephen and Andrew Lakoff. 2008. "The Vulnerability of Vital Systems: How 'Critical Infrastructure' Became a Security Problem." In Myriam D. Cavelty and Kristian S. Kristensen, eds. Securing "the Homeland": Critical Infrastructure, Risk and (In)security, 17-39. Miltan Park: Routledge.

Cooper, Timothy. 2008. "Challenging the 'Refuse Revolution': War, Waste and the Rediscovery of Recycling, 1900-1950." Historical Research 81(214):710-731.

2010. "Burying the 'Refuse Revolution': The Rise of Controlled Tipping in Britain, 19201960." Environment and Planning A 42(5):1033-1048.

Debord, Guy. 1992. The Society of the Spectacle. London: Rebel Press.

Foucault, Michel. 2008. The Birth of Biopolitics: Lectures at the College de France, 1978-1979. Basingstoke: Palgrave Macmillan.
Fraser, Nancy. 1992. "Sex, Lies, and the Public Sphere: Some Reflections on the Confirmation of Clarence Thomas." Critical Inquiry 18(3):595-612.

Geels, Frank W. 2006. "The Hygienic Transition from Cesspools to Sewer Systems (1840-1930): The Dynamics of Regime Transformation." Research Policy 35(7):1069-1082.

Geels, Frank and Johan Schot. 2007. "Typology of Sociotechnical Transition Pathways." Research Policy 36:399-417.

Gupta, Akhil. 2012. Red Tape: Bureaucracy, Structural Violence, and Poverty in India. Durham: Duke University Press.

Jones, Gwyn. 1973. Rural Life. London: Longman.

Jones, Peter. 2007. "Chapter Five: Cleanin' Windows. Park Hill Flats Sheffield." NAME OF BLOG, DATE OF ENTRY. Accessed from http://parkhillflats.webs.com/chapterfive.htm on DATE.

Latour, Bruno. 2005. Reassembling the Social: An Introduction to Actor-Network-Theory. Oxford: Oxford University Press.

Law, John and Annemarie Mol. 2008. "Globalisation in Practice: On the Politics of Boiling Pigswill." Geoforum 39:133-143.

Lets Recycle. 2006. "Digestion Firm Changes Procedures After Pollution Fine." November 3. Accessed from http://www.letsrecycle.com/news/latest-news/compost/digestion-firm-changes-proceduresafter-pollution-fine on DATE.

MacKenzie, Donald and Judy Wajcman, eds. 1999. The Social Shaping of Technology. Buckingham: McGraw Hill/Open University.

Marres, Noortje. 2004. "Tracing the Trajectories of Issues, and Their Democratic Deficits, on the Web: The Case of the Development Gateway and Its Doubles." Information Technology \& People 17(2):124-149. 2009. "Testing Powers of Engagement: Green Living Experiments, the Ontological Turn and the Undoability of Involvement." European Journal of Social Theory 12(1):117-133.

2012. Material Participation: Technology, the Environment, and Everyday Publics. New York: Palgrave Macmillan

Mitchell, Timothy. 2011. Carbon Democracy: Political Power in the Age of Oil. New York: Verso.

Mollona, Massimiliano. 2009. Made in Sheffield: An Ethnography of Industrial Work and Politics. London: Berghahn Books.

Murdoch, Jonathan and Andy Pratt. 1993. "Rural Studies: Modernism, Postmodernism and the 'PostRural." Journal of Rural Studies 9(4):411-427.

Owen, Gill. 1992. "Community Heating: UK Action Plan." Combined Heat and Power Association. World Energy Council.

Rabinow, Paul and Nikolas Rose. 2006. "Biopower Today." BioSocieties 1:195-217.

Reid, Donald. 1993. Paris Sewers and Sewermen: Realities and Representations. Cambridge: Harvard University Press.

Reno, Joshua. 2011a. "Motivated Markets: Instruments and Ideologies of Clean Energy in the United Kingdom." Cultural Anthropology 26(3):389-413.

.2011b. "Managing the Experience of Evidence: England's Experimental Waste Technologies and Their Immodest Witnesses." Science, Technology \& Human Values 366:842-863.

Rössler, Beate, ed. 2004. Privacies: Philosophical Evaluations. Stanford: Stanford University Press.

Santoro, Pablo. 2009. "From (Public?) Waste to (Private?) Value." Science Studies 22(1):3-23.

Seyd, Patrick. 1990. "Radical Sheffield': From Socialism to Entrepreneurialism." Political Studies 38(2):335-344

Sheffield Archives, Ukele Lady. 2011. "Reply \#133 in Park Hill Flats Chat Thread." Sheffield History, Sheffield History Chat, January 9. Accessed from http://www.sheffieldhistory.co.uk/forums/index. php?/topic/934-park-hill-flats/page-4 on DATE.

Sheffield City Council. 2010. Sources for the Study of Park Hill and Hyde Park Flats. Sheffield: Communities: Libraries, Archives and Information.

Warner, Michael. 2005. Publics and Counterpublics. New York: Zone Books. 
Watts, H. Doug. 2004. Discovering Cities: Sheffield. CITY: Geographical Association.

Winkler, Astrid. 2007. Sheffield City Report, CASE Report 45, Centre for Analysis of Social Exclusion.

Wynne, Brian. 1992. "Misunderstood Misunderstanding: Social Identities and Public Uptake of Science." Public Understanding of Science 1:281-304.

\section{Foreign Language Translations: (PLACEHOLDER ONLY!)}

A Baron, Some Guides, and a Few Ephebic Boys: Cultural Intimacy, Sexuality, and Heritage in Sicily [Keywords: Cultural intimacy, heritage, tourism, sex, power, Sicily]

Un barone, due guide e alcuni efebi. Intimità culturale, sessualità e patrimonio in Sicilia [Parole chiave: Intimità culturale, Patrimonio culturale, Turismo, Sessualità, Potere, Sicilia]

Um Barão, Alguns Guias Turísticos e uns Quantos Efebos: Intimidade Cultural, Sexualidade e Património na Sicília

[Palavras-chave: Intimidade cultural, património, turismo, sexo, poder, Sicília]

一个男爵, 数位领路人, 以及几个刚成年的男孩: 文化亲密性, 性和遗产在西西里岛

关键词：文化亲密性, 遗产, 旅游, 性, 权力, 西西里岛

Барон, кое-какие гиды, и несколько эфебических мальчиков: культурная интимность, сексуальность и наследие в Сицилии.

[Ключевые слова: культурная интимность, наследие, туризм, секс, власть, Сицилия]

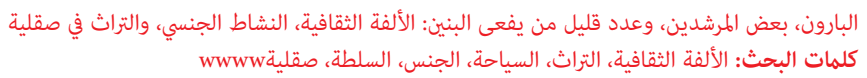

